\title{
Protective Effect of Curcumin on Cadmium-Induced Liver Apoptosis in Rats
}

\author{
Nihan BAYINDIR', Mukaddes ESREFOGLU'1, Meltem KUMAS'1, Meryem IRAZ², Siddıka KESGIN³ , Elif KILIC \\ 'Department of Histology and Embryology, Bezmialem Vakıf University, İstanbul, Turkey \\ ${ }^{2}$ Department of Medical Microbiology, Bezmialem Vakıf University, İstanbul, Turkey \\ ${ }^{3}$ Department of Medical Biochemistry, Bezmialem Vakıf University, İstanbul, Turkey
}

\section{ABSTRACT}

Objective: Cadmium (CD), which is used for many industrial purposes, is a toxic agent. CD accumulates in the liver; therefore, exposure to toxic doses of $\mathrm{Cd}$ results in hepatic damage. Studies in rats have shown that CD induces apoptosis in hepatocytes. Curcumin is a natural compound isolated from Curcuma longa. It has a powerful anti-inflammatory affect and scavenges reactive oxygen radicals. Additionally, it has been shown to have an anti-apoptotic effect in a dose-dependent manner. The aim of the present study was to evaluate the effects of therapeutic doses of curcumin on Cd-induced hepatic apoptosis as well as hepatic biochemical and inflammatory changes in Sprague-Dawley rats.

Methods: In this study, 24 female Sprague-Dawley rats (6 months old) were randomly assigned to four main groups ( $\mathrm{n}=6)$ : control, $\mathrm{CD}, \mathrm{CD}$ +curcumin, and curcumin. At the end of the experiment, after collecting blood samples from the heart, the rats were sacrificed and their livers were removed for histopathological and biochemical examinations. The number of apoptotic cells, total anti-oxidant status, total oxidant status, and thiol and MPO levels were measured in liver tissue; interleukin- 6 and procalcitonin levels were measured in sera.

Results: Chronic CD administration induced apoptosis. The number of apoptotic cells was significantly increased in the Cd group (almost 2 fold) compared to that in the control group. However, in the CD+curcumin group, the number of apoptotic cells was significantly decreased (almost 2 fold) compared to that in the Cd group. However, there were no statistically significant differences.

Conclusion: We suggest that curcumin protects the liver against toxin-induced apoptosis.

Keywords: Apoptosis, cadmium, curcumin, liver

\section{Introduction}

Cadmium (Cd), a heavy metal, is a highly toxic environmental agent with carcinogenic effects. The main sources of $\mathrm{Cd}$ that are often used in industries are fossil fuels, wastewater, mineral deposits, and tobacco products (1). Cd enters the human body through air, water, and nutrients and accumulates in various organs $(2,3)$. Because its half-life is very long and it cannot be reduced in the body, it accumulates in various organs such as the liver, kidney, lung, heart, and bone, leading to the damage of DNA, activation of proto oncogenes, and inhibition of DNA repair mechanisms by inducing oxidative stress formation in organs at the cellular level (46). Studies have shown that $\mathrm{Cd}$ induces apoptosis in many organs such as the liver and kidney $(7,8)$. However, the signaling pathway through which $\mathrm{Cd}$ acts is not yet completely clear. Cd toxicity has been reported to lead to various diseases such as renal and hepatic failure, osteoporosis, arteriosclerosis, anemia, and cancer (9-12).

Curcumin is obtained from yellow turmeric (Curcuma longa L.), which is used as a spice in foods. It is known that curcumin has anti-inflammatory, anti-microbial, and antioxidant properties (13-18). The anti-carcinogenic effect of curcumin has been demonstrated in cell cultures and experimental animal models (19-21).

In this study, the effect of chronic $\mathrm{Cd}$ application on the rate of apoptosis in the liver of adult rats was investigated. In addition, the total oxidant status (TOS), total antioxidant capacity (TAC), thiol, and myeloperoxidase (MPO) levels were measured in liver tissues. Serum interleukin-6 (IL-6) and procalcitonin (PCT) levels 
were also determined. This study aimed to investigate the effect of curcumin, which was applied at therapeutic doses, on apoptotic, biochemical, and inflammatory changes following Cd application.

\section{Methods}

\section{Method of Experiment}

Twenty-four 6-month-old female Sprague Dawley rats were used. The rats were randomly divided into the following four groups: Group I $(n=6)$, control group; Group II $(n=6)$, Cd group; Group III $(n=6)$, $\mathrm{Cd}+$ curcumin group $(\mathrm{Cd}+\mathrm{Cur})$; and Group IV $(\mathrm{n}=6)$, curcumin group (Cur). The rats received $\mathrm{Cd}$ intraperitoneally (ip.) at a dose of $0.5 \mathrm{mg} / \mathrm{kg} / \mathrm{day}$, and received Cr ip. at a dose of $50 \mathrm{mg} / \mathrm{kg} /$ day for 10 days. Cr was applied for 10 days after application of cadmium at the co-treated group. Curcumin dissolved in olive oil. Curcumin, prepared in the same way, was intraperitoneally administered at a dose of $50 \mathrm{mg} / \mathrm{kg}$ to the rats in the Cur group for 10 days. Olive oil was intraperitoneally administered to rats in the control group at a dose of 0.5 $\mathrm{mL}$ for 10 days. At the end of the experiment period, general anesthesia was administered to all the rats using $80 \mathrm{mg} / \mathrm{kg}$ ketamine (Ketalar, Pfizer, Turkey) and 5 $\mathrm{mg} / \mathrm{kg}$ xylase $\mathrm{HCl}$ (Rompun, Bayer, Turkey), and blood samples were obtained from the heart. In addition, liver tissue samples were also obtained. Half of the tissues were temporarily preserved at $-80^{\circ} \mathrm{C}$ in a freezer until biochemical tests were performed. The other half was placed in $10 \%$ formaldehyde-buffered solution for use in the immunofluorescence methods.

This study was conducted at the same center following the approval of the Bezmialem Vakıf University Research Center, Experimental Animals Ethics Committee.

\section{TUNEL Method}

Liver specimens fixed with $10 \%$ neutral buffered formalin for microscopic examination were embedded in paraffin with a routine histological follow-up. The TUNEL method (terminal deoxynucleotidyl transferase-mediated dUTP-X nick end labeling assay, Roche-11 684795 910-kit) was applied to the sections taken from paraffin blocks with a thickness of $4 \mu \mathrm{m}$, according to the recommended procedure in the kit. The number of apoptotic cells was obtained by counting TUNEL positive cells in the immunofluorescence microscope (Nikon Eclipse $80 \mathrm{i})$ in randomly selected 20 fields at $\times 20$ magnification on each section.

\section{Biochemical Analysis}

Liver samples were weighed and homogenized for 3 $\mathrm{min}$ at $16000 \mathrm{rpm}$ in Tris- $\mathrm{HCl}$ buffer ( $\mathrm{pH} 7.4)$. Homogenization was achieved in an ice bucket. The homogenate was centrifuged at $5000 \times \mathrm{g}$ for $1 \mathrm{~h}\left(\mathrm{at}+4^{\circ} \mathrm{C}\right)$ levels of the supernatant samples were determined using the Erel method (Rel Assay Diagnostics, Gaziantep, Turkey).

Determination of Serum Inflammatory Factor Levels Blood samples obtained from the heart were centrifuged at $3000 \mathrm{rpm}$ for $5 \mathrm{~min}$ to obtain the serum. Serum samples were stored at $-80^{\circ} \mathrm{C}$ until further analysis. IL-6 and PCT levels were measured using a commercial kit (Rat IL-6 Platinum ELISA, eBioscience, Bender MedSystems GmbH, Vienna, Austria), (Rat PCT Elisa Kit, Eastbio Pharm, Hangzhou East Biopharm Co., Hangzhou, China). The method was performed according to the procedures in the company kit.

\section{Statistical analysis}

All statistical analysis was performed using the GraphPad Prism 6 (USA) program. The Dunnett's multiple comparison test was used as post-hoc test. The results were evaluated at the significance level of $\mathrm{p}<0.05$.

\section{Results}

\section{Apoptosis Findings}

The mean numbers of apoptotic cells were $132.50 \pm 58.52$ in the control group, $242.66 \pm 170.02$ in the Cd group, $112.33 \pm 15.38$ in the $\mathrm{Cd}+\mathrm{Cur}$ group, and $75.16 \pm 26.55$ in the Cur group. Although the numbers of apoptotic cells in all the groups were quite different, there was no statistically significant difference. It was remarkable that the values of the control and $\mathrm{Cd}+\mathrm{Cur}$ group were very close. The number of apoptotic cells was lower in the Cur group than in the control group (Table 1, Figures $1,2)$.

\section{Oxidative Stress Parameters}

The mean TOS levels were $8.26 \pm 2.55$ in the control group, $11.31 \pm 3.56$ in the Cd group, $9.70 \pm 2.42$ in the $\mathrm{Cd}+$ Cur group, and $12.80 \pm 1.99$ in the Cur group. The mean TAC levels were $1.13 \pm 1.55$ in the control group, $1.08 \pm 0.87$ in the $\mathrm{Cd}$ group, $1.00 \pm 1.20$ in the $\mathrm{Cd}+\mathrm{Cur}$ group, and $0.59 \pm 0.60$ in the Cur group. Thus, the TOS level increased in the Cd group compared with the control group, while the TAC level decreased. TOS and TAC levels decreased in the $\mathrm{Cd}+\mathrm{Cur}$ group compared with the $\mathrm{Cd}$ group. The highest TOS and lowest TAC levels were in the Cur group. These results were not statistically significant (Figure 3, 4).

The mean thiol levels were $0.60 \pm 0.46$ in the control group, $0.36 \pm 0.24$ in the $\mathrm{Cd}$ group, $0.45 \pm 0.22$ in the $\mathrm{Cd}+\mathrm{Cur}$ group, and $0.33 \pm 0.12$ in the Cur group. Thus, the thiol level decreased in the Cd group compared with the control group, whereas it increased in the $\mathrm{Cd}+\mathrm{Cur}$ group compared with the $\mathrm{Cd}$ group. The thiol level was lowest in the Cur group. These results were not statistically significant (Figure 5). 

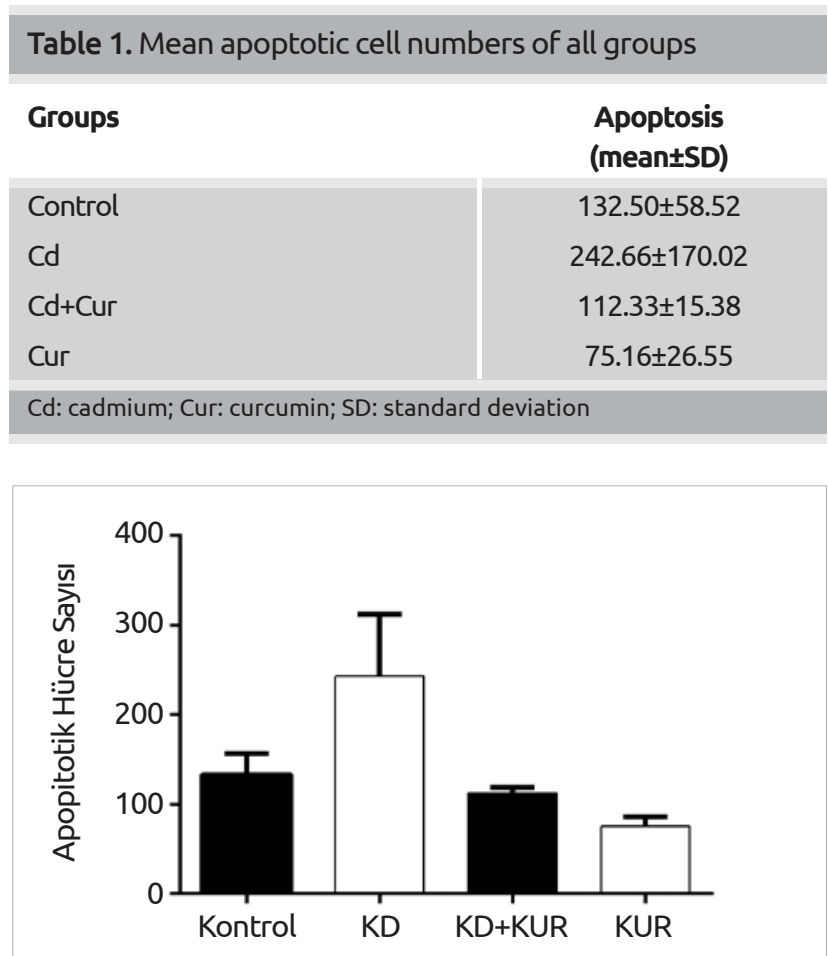

Figure 1. The average number of apoptotic cells in all groups
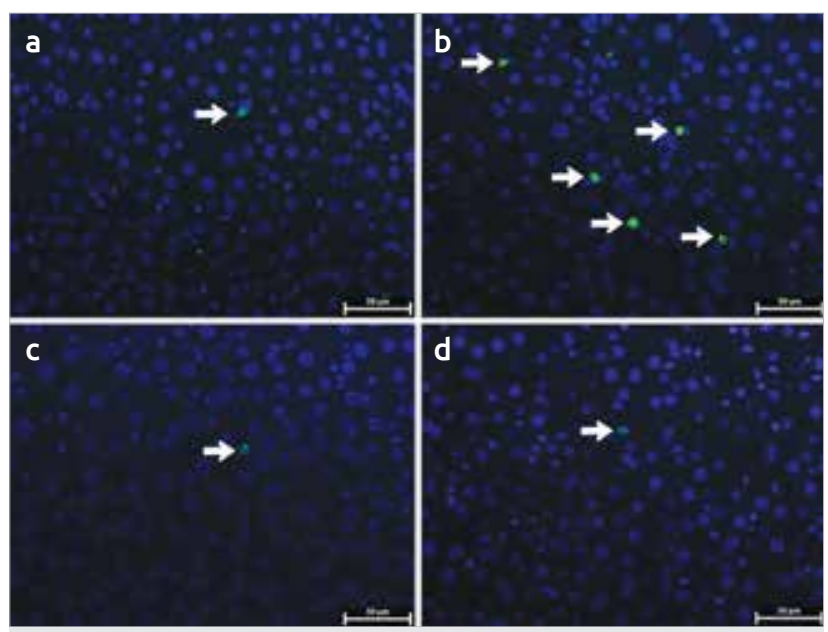

Figure 2. (a-d). Apoptotic cells are shown in hepatic liver sections (arrow) (a) control group; (b) Cd group; (c), Cd+Cur group; (d), Cur group (Tunel Method at 40x magnification; Bar, $50 \mu \mathrm{m}$ )

The mean MPO levels were $1449.89 \pm 868.12$ in the control group, $1739.92 \pm 901.75$ in the Cd group, $1269.58 \pm 690.12$ in the $\mathrm{Cd}+\mathrm{Cur}$ group, and $1719.35 \pm 529.82$ in the Cur group. The MPO level was found to be the highest in the $\mathrm{Cd}$ group and the lowest in the $\mathrm{Cd}+\mathrm{Cur}$ group. These results were not statistically significant (Figure 6).

The mean values of the biochemical data are given in Table 2.

\section{Inflammatory Marker Parameters}

The mean IL-6 levels were $55.39 \pm 39.23$ in the control group, $66.96 \pm 20.56$ in the $\mathrm{Cd}$ group, $53.96 \pm 29.58$

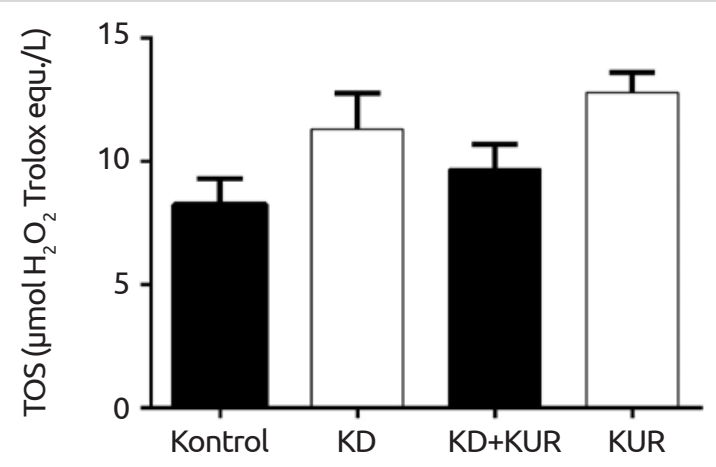

Figure 3. TOS averages of all groups TOS: total oxidant status

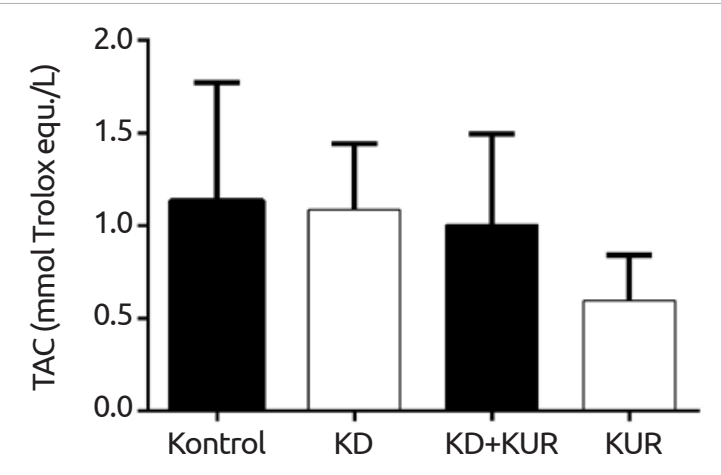

Figure 4. TAC averages of all groups TAC: total antioxidant capacity

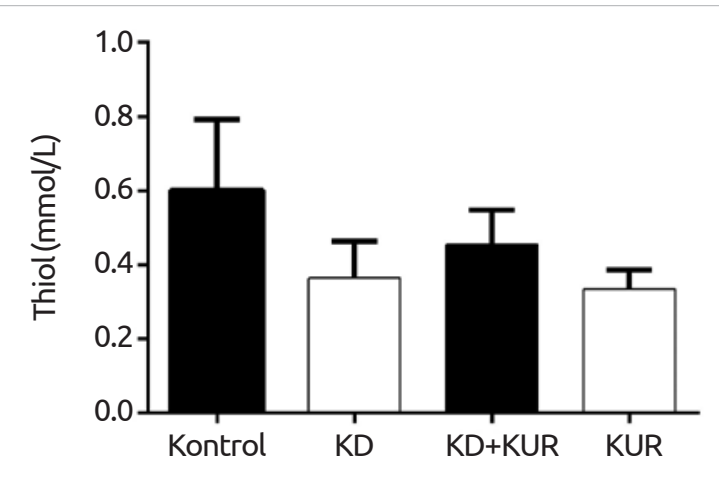

Figure 5. Thiol averages of all groups

in the $\mathrm{Cd}+\mathrm{Cur}$ group, and $87.50 \pm 59.71$ in the Cur group. The highest IL-6 level was observed in the Cur group. Compared with the control group, the IL- 6 level increased in the $\mathrm{Cd}$ group and was the lowest in the $\mathrm{Cd}+\mathrm{Cur}$ group. These results were not statistically significant (Figure 7).

The mean PCT levels were $480.90 \pm 321.48$ in the control group, $1750.19 \pm 250.38$ in the Cd group, $694.13 \pm 434.54$ in the $\mathrm{Cd}+\mathrm{Cur}$ group, and $681.10 \pm 342.87$ in the Cur group. The highest PCT level was observed in the Cd group. The PCT level decreased in the $\mathrm{Cd}+\mathrm{Cur}$ group. 


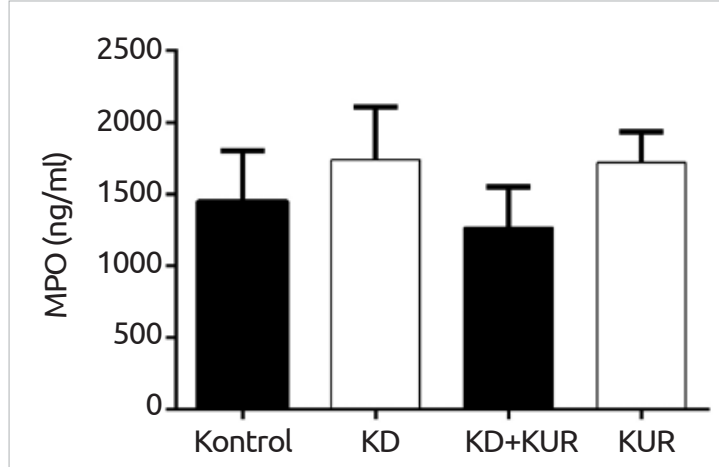

Figure 6. MPO averages of all groups MPO: myeloperoxidase

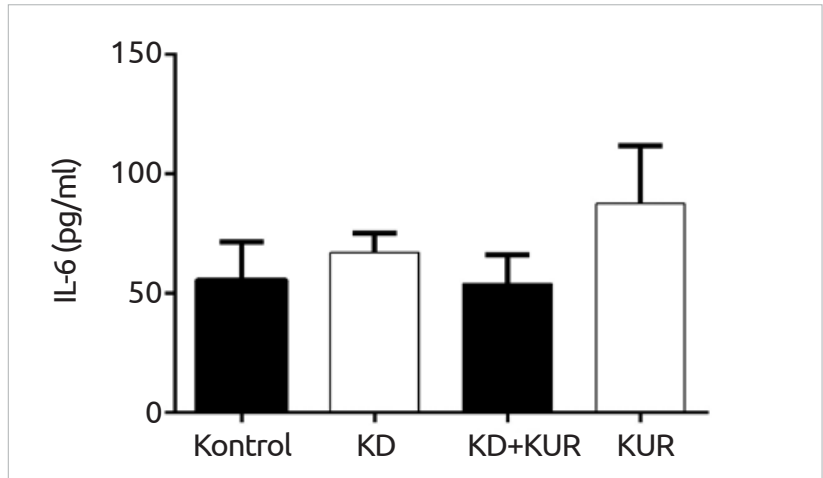

Figure 7. IL-6 averages of all groups

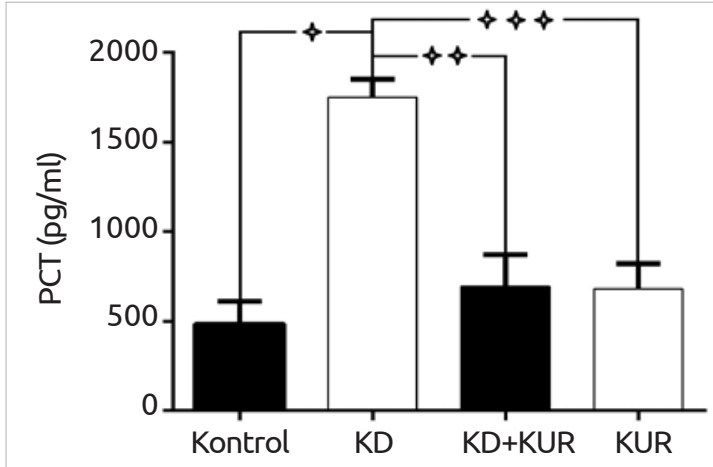

Figure 8. PCT averages of all groups PCT: procalcitonin

$*, * *, * * * p<0.000$

These results were statistically significant $(\mathrm{p}<0.000$; Figure 8).

The mean values of the parameters of the inflammatory markers are given in Table 3 .

\section{Discussion}

A large amount of $\mathrm{Cd}$ entering the body is absorbed through the intestines and transported to the liver by portal circulation (22). Cd accumulating in hepatocytes
Table 2. Mean biochemical values of all groups

\section{Mean Biochemical Values (mean \pm SD)}

\begin{tabular}{|c|c|c|c|c|}
\hline Groups & $\begin{array}{c}\text { TAC } \\
\text { (mmol } \\
\text { Trolox } \\
\text { equ./L) }\end{array}$ & $\begin{array}{c}\text { TOS } \\
\text { ( } \mu \text { mol } \\
\mathrm{H}_{2} \mathrm{O}_{2} \\
\text { equ./L) }\end{array}$ & $\begin{array}{c}\text { Thiol } \\
\text { (mmol/L) }\end{array}$ & $\begin{array}{c}\text { MPO } \\
\text { (ng/mL) }\end{array}$ \\
\hline Control & $1.13 \pm 1.55$ & $8.26 \pm 2.55$ & $0.60 \pm 0.46$ & $1449.89 \pm 868.12$ \\
\hline $\mathrm{Cd}$ & $1.08 \pm 0.87$ & $11.31 \pm 3.56$ & $0.36 \pm 0.24$ & $1739.92 \pm 901.75$ \\
\hline $\mathrm{Cd}+\mathrm{Cur}$ & $1.00 \pm 1.20$ & $9.70 \pm 2.42$ & $0.45 \pm 0.22$ & $1269.58 \pm 690.12$ \\
\hline Cur & $0.59 \pm 0.60$ & $12.80 \pm 1.99$ & $0.33 \pm 0.12$ & $1719.35 \pm 529.82$ \\
\hline
\end{tabular}

Cd: cadmium; Cur: curcumin; SD: standard deviation;

TAC: total antioxidant capacity; TOS: total oxidant status; MPO: myeloperoxidase

Table 3. Results of the mean inflammatory markers of all groups

\section{Inflammatory Markers (mean $\pm S D$ )}

\begin{tabular}{l|c|c|}
\hline Groups & IL-6 (pg/mL) & PCT $(\mathbf{p g} / \mathrm{mL})$ \\
\hline Control & $55.39 \pm 39.23$ & $480.90 \pm 321.48^{*}$ \\
Cd & $66.96 \pm 20.56$ & $1750.19 \pm 250.38 * * *, * * *$ \\
Cd+Cur & $53.96 \pm 29.58$ & $694.13 \pm 434.54 * *$ \\
Cur & $87.50 \pm 59.71$ & $681.10 \pm 342.87 * * *$ \\
\hline
\end{tabular}

Cd: cadmium; Cur: curcumin; SD: standard deviation; PCT: procalcitonin ${ }^{*} \mathrm{p}<0.000$; Control and $\mathrm{Cd}$ groups

${ }^{* *} \mathrm{p}<0.000$; $\mathrm{Cd}$ and $\mathrm{Cd}+$ Cur groups

*** $p<0.000 ; \mathrm{Cd}$ and Cur groups

In the primary pathway, $\mathrm{Cd}$ causes direct damage. $\mathrm{Cd}$ binds to the sulfhydryl groups of some of the important molecules in the mitochondria and induces oxidative stress by inactivating the thiol groups. In the secondary pathway, it is the inflammatory pathway that is achieved by inducing the activation of Kupffer cells with the secretion of cytotoxic and inflammatory mediators (23). Studies have demonstrated that $\mathrm{Cd}$ induces apoptosis in many organs such as the liver and kidney $(7,8)$. However, the signaling pathway through which $\mathrm{Cd}$ acts is not completely clear.

Acute exposure to Cd causes severe liver damage (23). In addition, it causes cellular damage in many organs such as kidneys, testes, pancreas, and bone. Thus, cells die because of necrosis or apoptosis (24-27). Apoptosis is a highly complex cell death mechanism, which is induced by many intracellular signal pathways. Previous studies have shown that $\mathrm{Cd}$ increases oxidative stress and induces apoptosis (28-31). In our study, it was observed that the number of apoptotic cells in the liver of rats of the Cd group was two times higher than that 
in liver of rats of the control group, and the TOS level increased, whereas the TAC level decreased. It is known that curcumin has anti-proliferative, apoptosis-inducing, anti-tumorigenic effects (32-34). However, studies conducted in the field of cell culture have shown that curcumin inhibits chemotherapy-induced apoptosis by inhibiting the formation of reactive oxygen species in human breast cancer cells, and it inhibits apoptotic biochemical changes in human epidermoid carcinoma cells $(35,36)$. Similarly, in our study, the increased number of apoptotic cells in the Cd group was observed to decrease by half in the $\mathrm{Cd}+\mathrm{Cur}$ group.

Under normal conditions, free radicals that are degradation products of oxygen used during cell metabolism are destroyed by the intracellular antioxidant system and are prevented from damaging the cell. However, the fact that the increasing amount of free radicals in various pathological conditions cannot be neutralized by the suppressed antioxidant system can lead to cell death. In our study, the Cd group had a higher TOS level and lower TAC level than the control group. These data suggest that $\mathrm{Cd}$ leads to oxidative stress. The TOS level decreased in the $\mathrm{Cd}+\mathrm{Cur}$ group. It can be said that curcumin is successful in reducing the TOS level in hepatocytes, but it does not have much effect in increasing the antioxidant capacity because the administration of curcumin does not lead to a significant increase in the mean TAC levels.

Neutrophils that migrate to the inflammatory region significantly contribute to oxidative damage by generating free radicals. Increased MPO levels in the tissue indicate inflammation and thus, oxidative stress. Similarly, thiol levels vary depending on the oxidative stress. Free radicals cause the oxidation of thiol groups in proteins, resulting in oxidative protein damage. The thiol and oxidative damage levels are inversely proportional. In our study, the mean MPO level of the Cd group was higher than that of the control group. This level was lower in the $\mathrm{Cd}+$ Cur group than in the $\mathrm{Cd}$ group. It was observed that the thiol level in the $\mathrm{Cd}$ group decreased compared with that in the control group and increased in the $\mathrm{Cd}+\mathrm{Cur}$ group compared with that the $\mathrm{Cd}$ group. In the light of these data, it can be said that inflammation and oxidative stress increased in the Cd group and that curcumin decreased the cell damage by suppressing the inflammation.

In addition, the high average TOS level and low TAC level in the Cur group suggest that curcumin administration as an antioxidant in healthy people may induce oxidative stress by acting as a prooxidant, which is true for many other antioxidants. Any antioxidant that acts as an antioxidant and free radical scavenger in tissues where oxidative stress is intense may cause oxidative damage as a reverse prooxidant in healthy tissues. Our results are supported by the average MPO and thiol levels observed in the Cur group. MPO and thiol levels of the Cur group were also very close to the $\mathrm{Cd}$ group.

Curcumin is a compound that has antioxidant properties. However, studies have shown that curcumin has both cytoprotective and cytotoxic effects. Studies conducted in the field of cell culture have shown that when $\mathrm{H}_{2} \mathrm{O}_{2}$ and curcumin were simultaneously added to the culture medium of NG108-15 nerve cells, curcumin protected the cells from $\mathrm{H}_{2} \mathrm{O}_{2}$-induced oxidative damage. However, it could not tolerate the cytotoxic effect of $\mathrm{H}_{2} \mathrm{O}_{2}$ in the cells that were first treated with curcumin and in which damage was produced with $\mathrm{H}_{2} \mathrm{O}_{2}$ later (37). In different studies, it has been reported that curcumin is a dose-dependent prooxidant $(38,39)$.

IL-6 is a multifunctional cytokine that is involved in the regulation of the immune response, hematopoiesis, and inflammation. Various toxins, bacterial and viral infections, and cancers lead to an increase in IL-6 levels and in many other cytokines (40). Souza et al. (41) have shown that $\mathrm{CdCl}_{2}$ in cell cultures increases the Il-6 expression in HepG2 cells. In different studies, it has been shown that Cd increases and curcumin decreases IL-6 levels $(42,43)$. Our study demonstrated that the serum IL-6 level increased in the Cd group $(254.09 \pm 40.27)$ and decreased in the $\mathrm{Cd}+\mathrm{Cur}$ group $(209.77 \pm 39.92)$.

PCT is a calcitonin hormone precursor that is produced by neuroendocrine cells in the intestines, pancreas, lung, and in the $\mathrm{C}$ cells of the thyroid and is an early marker of inflammation (44). While the PCT level in the $\mathrm{Cd}$ group increased, it decreased in the $\mathrm{Cd}+\mathrm{Cur}$ group $(\mathrm{p}<0.000)$. The similar course of PCT and IL- 6 levels may be interpreted as $\mathrm{Cd}$ damage increases inflammation and curcumin decreases it.

\section{Conclusion}

Thus, curcumin reduced Cd-induced apoptotic cell death and suppressed inflammation and oxidative stress. We also concluded that curcumin, whose prooxidant characteristic was identified and which is planned to be used in healthy people as a prophylactic agent, should be considered, and further studies should be conducted in this regard.

Ethics Committee Approval: Ethics committee approval was received for this study from the central ethics committee for laboratory animals of Bezmialem University.

Informed Consent: Informed consent is not required in this study.

Peer-review: Externally peer-reviewed.

Author Contributions: Concept - N.B., M.E., M.K., M.I., S.K., E.K.; Design - N.B., M.E., M.K., M.I., S.K., E.K.; Supervision - 
N.B., M.E., M.K., M.I., S.K., E.K.; Funding - N.B., M.E., M.K., M.I., S.K., E.K.; Materials - N.B., S.K.; Data Collection and/ or Processing - N.B., M.K., S.K.; Analysis and/or Interpretation - N.B., M.E., M.I., E.K.; Literature Review - N.B., M.K.; Writing - N.B., M.E.; Critical Review - N.B., M.E., M.K., M.I., S.K., E.K.

Conflict of Interest: No conflict of interest was declared by the authors.

Financial Disclosure: The authors declared that this study has received no financial support.

\section{References}

1. Muntau H, Baudo R. Sources of cadmium, its distribution and turnover in the freshwater environment. IARC 1992; 118: 13348.

2. Nriagu J. A silent killer of environmental metal poisoning. Environ Pollut 1988; 50: 139-61. [CrossRef]

3. Flora SJS, Mittal M, Mehta A. Heavy metal induced oxidative stress \& its possible reversal by chelation therapy. Indian J Med Res 2008; 128: 501-23.

4. Bertin G, Averbeck D. Cadmium: cellular effects, modifications of biomolecules, modulation of DNA repair and genotoxic consequences (a review). Biochimie 2006; 88: 1549-59. [CrossRef]

5. Joseph P. Mechanism of cadmium carcinogenesis. Toxicol Appl Pharmacol 2009; 238: 272-79. [CrossRef]

6. Giaginis C, Gatzidou E, Theocharis S. DNA repair systems as targets of cadmium toxicity. Toxicol Appl Pharmacol 2006; 213: 282-90. [CrossRef]

7. Xie J, Shaikh ZA. Cadmium-induced apoptosis in rat kidneyepithelial cells involves modulation of nuclear factor-kappa-B activity. Toxicol Sci 2006; 91: 299-308. [CrossRef]

8. Pham TN, Marion M, Denizeau F, Jumarie C. Cadmium-induced apoptosis in rat hepatocytes does not necessarily involve caspase-dependent pathways. Toxicol. In Vitro 2006; 20: 133142. [CrossRef]

9. Jarup L, Akesson A. Current status of cadmium as an environmental health problem. Toxicol Appl Pharm 2009; 238: 201-8 [CrossRef]

10. Goyer RA, Cherian MG. Renal effects of metals. In Metal Toxicology 1995; 389-412. [CrossRef]

11. Åkesson A, Bjellerup P, Lundh T, Lidfeldt J, Nerbrand C, Samsioe G, Skerfving S, Vahter M. Cadmium-Induced Effects on Bone in a Population-Based Study of Women. Environ Health Perspect 2006; 114: 830-4. [CrossRef]

12. Waalkes MP, Anver MR, Diwan BA. Chronic toxic and carcinogenic effects of oral cadmium in the Noble (NBL/Cr) rat: Induction of neoplastic and proliferative lesions of the adrenal, kidney, prostate, and testes. J Toxicol Environ Health 1999; 58: 199-214. [CrossRef]

13. Tonnesen, HH. Chemistry of curcumin and curcuminoids. In Phenolic Compounds in Food and their Effect of Health, Vol. 1: Analysis, Occurrence and Chemistry 1992. [CrossRef]

14. Satoskar RR, Shah SJ, Shenoy SG. Evaluation of antiinflammatory property of curcumin (diferuloyl methane) in patients with postoperative inflammation. Int J Clin Pharmacol Ther Toxicol 1986; 24: 651-4

15. Negi PS, Jayaprakasha GK, Jagan MRL, Sakariah KK. Antibacterial activity of turmeric oil: a byproduct from curcumin manufacture. J Agric Food Chem 1999; 47: 4297-300. [CrossRef]

16. Sharma OP. Antioxidant activity of curcumin and related compounds. Biochem. Pharmacol 1976; 25: 1811-12. [CrossRef]

17. Ruby AJ, Kuttan G, Dinesh BK, Rajasekharan KN, Kuttan R. Anti-tumor and antioxidant activity of natural curcuminoid. Cancer Lett 1995; 94: 79-83. [CrossRef]
18. Araujo CC, Leon LL. Biological activities of Curcuma longa L. Mem Inst Oswaldo Cruz 2001; 96, 723-8. [CrossRef]

19. Chauhan DP. Chemotherapeutic potential of curcumin for colorectal cancer. Curr Pharm Des 2002; 8: 1695-706. [CrossRef]

20. Aggarwal BB, Kumar A, Bharti AC. Anticancer potential of curcumin: preclinical and clinical studies. Anticancer Res 2003; 23: 363-98.

21. Mahady GB, Pendland SL, Yun G, Lu ZZ. Turmeric (Curcuma longa) and curcumin inhibit the growth of Helicobacter pylori, a group 1 carcinogen. Anticancer Res 2002; 22: 4179181.

22. DelRaso NJ, Foy BD, Gearhart JM, Frazier JM. Cadmium uptake kinetics in rat hepatocytes: correlation for albumin binding. Toxicol Sci 2003; 72: 19-30. [CrossRef]

23. Rikans LE, Yamano T. Mechanisms of cadmium-mediated acute hepatotoxicity. J Biochem Mol Toxicol 2000; 14: 110-7. [CrossRef]

24. Axelsson B, Piscator M. Renal damage after prolonged exposure to cadmium. An experimental study. Arch Environ Health 1966; 12: 360-73. [CrossRef]

25. Martynowicz H, Skoczyńska A, Karczmarek-Wdowiak B, Andrzejak R. Effect of cadmium on testis function. Med Pr 2005; 56: $167-74$.

26. Rastogi RB, Singhal RL. Effect of chronic cadmium treatment on rat adrenal catecholamines. Endocr Res Commun 1975; 2: 87-94. [CrossRef]

27. Jarup L, Alfven T. Low level cadmium exposure, renal and bone effects--the OSCAR study. Biometals 2004; 17: 505-9. [CrossRef]

28. Hassoun EA, Stohs SJ. Cadmium induced production of superoxide anion and nitric oxide, DNA single strand breaks and lactate dehydrogenase leakage in J774a. 1 cell cultures. Toxicology 1996; 112: 219-26. [CrossRef]

29. Tzirogiannis, KN, Panoutsopoulos GI, Demonakou MD, Hereti RI, Alexandropoulou KN, Basayannis AC, et al. Time-course of cadmium-induced acute hepatotoxicity in the rat liver: the role of apoptosis. Archives of Toxicology 2003; 77: 694-701. [CrossRef]

30. Kim MS, Kim BJ, Woo HN, Kim KW, Kim KB, Kim IK, et al. Cadmium-induced caspase-mediated cell death: suppression by Bcl-2. Toxicology 2000; 145: 27-37. [CrossRef]

31. Li M, Kondo T, Zhao QL, Li FJ, Tanabe K, Arai Y, et al. Apoptosis induced by cadmium in human lymphoma U937 cells through $\mathrm{Ca} 2+-$ calpain and caspase-mitochondria- dependent pathway. Journal of Biological Chemistry 2000; 275: 39702-9. [CrossRef]

32. Panchal HD, Vranizan K, Lee CY, Ho J, Ngai J, Timiras PS. Early Anti-Oxidative and Anti-Proliferative Curcumin Effectson Neuroglioma Cells Suggest Therapeutic Targets. Neurochem Res 2008; 33: 1701-10. [CrossRef]

33. Chen HW, Huang HC. Effect of curcumin on cell cycle progression and apoptosis in vascular smooth muscle cells. British Journal of Pharmacology 1998; 124: 1029-40. [CrossRef]

34. Kuo ML, Huang TS, Lin JK. Curcumin, an antioxidant and anti-tumor promoter, induces apoptosis in human leukemia cells. Biochimica et Biophysica Acta (BBA) - Molecular Basis of Disease 1996; 1317: 95-100. [CrossRef]

35. Somasundaram S, Edmund NA, Moore DT, Small GW, Shi YY, Orlowski RZ. Dietary Curcumin Inhibits Chemotherapyinduced Apoptosis in Models of Human Breast Cancer. Cancer Research 2002; 62: 3868-75.

36. Chan WH, Wu CC, Yu JS. Curcumin Inhibits UV IrradiationInduced Oxidative Stress and Apoptotic Biochemical Changes in Human Epidermoid Carcinoma A431 Cells. Journal of Cellular Biochemistry 2003; 90: 327-38. [CrossRef] 
37. Mahakunakorn P, Tohda M, Murakamı Y, Matsumoto K, Watanabe H, Vajaragupta O. Cytoprotective and Cytotoxic Effects of Curcumin: Dual Action on H2O2-Induced Oxidative Cell Damage in NG108-15 Cells. Biol Pharm Bull 2003; 26: 725-8. [CrossRef]

38. Halliwell B. Are polyphenols antioxidants or pro-oxidants? What do we learn from cell culture and in vivo studies? Arch Biochem Biophys 2008; 476: 107-12. [CrossRef]

39. Chattopadhay D, Somaiah A, Raghunathan D, Thirumurugan K. Dichotomous effect of caffeine, curcumin, and naringenin on genomic DNA of normal and diabetic subjects. Scientifica 2014; 1-7. [CrossRef]

40. Akramiene D, Kondrotas A, Didziapetriene J, Kevelaitis E. Effects of beta-glucans on the immune system. Medicina (Kaunas) 2007; 43: 597-606.

41. Souza V, Escobar Md Mdel C, Gómez-Quiroz L, Bucio L, Hernández E, Cossio EC, Gutiérrez-Ruiz MC, Acute cadmium exposure enhances AP-1 DNA binding and induces cytokines expression and heat shock protein 70 in HepG2 cells. Toxicology 2004; 197: 213-28. [CrossRef]

42. Alghasam A, Salem TA, Meki AR. Effect of cadmium pollutes water on plasma levels of tumor necrosis factor- $\alpha$, interleukin- 6 and oxidative status biomarkers in rats: protective effect of curcumin. Food Chem Toxicol 2013; 59: 160-4. [CrossRef]

43. Rennolds J, Malireddy S, Hassan F, Tridandapani S, Parinandi N, Boyaka PN, Cormet-Boyaka E. Curcumin regulates airway epithelial cell cytokine responses to the pollutant cadmium. Biochem Biophys Res Commun 2012; 417: 256-61. [CrossRef]

44. Taga T, Kishimoto T. Gp130 and the interleukin-6 family of cytokines. Annu Rev Immunol 1997; 15: 797-819.Intis dem hilit aut omnimodis isciatem nones sitatiur? [CrossRef] 